\begin{tabular}{|l|l|l||}
\hline \multicolumn{2}{|c|}{ PublisherInfo } \\
\hline \hline PublisherName & $:$ & BioMed Central \\
\hline \hline PublisherLocation & $:$ & London \\
\hline \hline PublisherImprintName & $:$ & BioMed Central \\
\hline \hline
\end{tabular}

\title{
DOG patrol
}

\begin{tabular}{|l|l|l||}
\hline \multicolumn{2}{|c|}{ ArticleInfo } \\
\hline \hline ArticleID & $:$ & 4529 \\
\hline \hline ArticleDOI & $:$ & $10.1186 /$ gb-spotlight-20020715-02 \\
\hline \hline ArticleCitationID & $:$ & spotlight-20020715-02 \\
\hline \hline ArticleSequenceNumber & $:$ & 195 \\
\hline \hline ArticleCategory & $:$ & Research news \\
\hline ArticleFirstPage & $:$ & 1 \\
\hline \hline ArticleLastPage & $:$ & 2 \\
\hline \hline & & RegistrationDate : 2002-7-15 \\
\hline ArticleHistory & $:$ & OnlineDate \\
\hline \hline ArticleCopyright & $:$ & BioMed Central Ltd2002-7-15 \\
\hline \hline ArticleGrants & $:$ & \\
\hline \hline ArticleContext & $:$ & 130593311 \\
\hline \hline
\end{tabular}




\section{Jonathan B Weitzman}

Email: jonathanweitzman@hotmail.com

The importance of maintaining genome integrity is highlighted by diseases that arise upon loss of the mechanisms that ensure correct DNA replication and repair. In an Advanced Online Publication in Nature Genetics, Cheung et al. describe a mutator phenotype in Caenorhabditis elegans that is associated with deletions in polyguanine tracts and is caused by disruption of a new gene that they have nicknamed dog-1 (for deletions of guanine-rich DNA) (Nature Genetics 8 July 2002, DOI:10.1038/ ng928). The $d o g-1$ gene encodes a protein containing a DEAH helicase domain. Disruptions within the dog-1 gene, or RNAi experiments, led to variable deletions of G-rich tracts around the C. elegans genome, without affecting other repeat structures or telomeres. Deletions were generally observed in tracts containing more than 22 guanine nucleotides. Cheung et al. propose that DOG-1 is important for resolving secondary structures of G-rich DNA and predict that homologs may exist in other species.

\section{References}

1. Genome maintenance mechanisms for preventing cancer.

2. Nature Genetics, [http://www.nature.com/ng/] 